\title{
Methods of Teaching University Students and Students of the Continuing Education System using Intelligent Information Systems
}

\author{
Ruzieva Dilnoz Isamjanovna, Abdullaeva Shahzoda Abdullaevna, Abdullaev Farhod \\ Abdurashidovich
}

\begin{abstract}
This article was written with the aim of theoretically substantiating, developing, and testing experimental methods for teaching university students and students of the advanced training system for computer specializations using intelligent information systems. The following tasks are solved in the article as: 1. To analyze the theoretical and methodological foundations of the use of ICT in teaching 2. To design and implement an intelligent information system in students' training that demonstrates the didactic potential of these systems. 3 . To substantiate the criteria for the levels of understanding of university students and students of the advanced training system of educational material and formalize them, laying in the capabilities of an intelligent information system. 4. To develop methods and means of teaching university students and students of the continuing education system using intelligent information systems. 5. Experimental search to verify the effectiveness of the application of the developed methodology. Based on the problem, a training methodology was developed, didactic foundations were determined and conclusions were drawn.
\end{abstract}

Keywords: information system, ICT, continuing education system, media materials, intelligent systems.

\section{INTRODUCTION}

The decrease in population growth a constantly changing in Relevance of the problem and research topics. At present, the social need for specialists with a high level of cognitive and creative potential, owning information technologies and applying them in solving professional and social problems is clearly defined. This need poses a challenge for the educational system to master a new paradigm oriented to the person and connecting with him the new requirements of production and society.

At the socio-pedagogical level, the relevance of the

Revised Manuscript Received on December 30, 2019.

* Correspondence Author

D.I.Ruzieva, Head of Department of General Pedagogy, Tashkent State Pedagogical University named after Nizami, Tashkent city, Uzbekistan. Email: dilnoz68@inbox.ru.

Sh.A.Abdullaeva, Professor of Faculty of Social Science, Chair of Education, The National University of Uzbekistan after named Mirzo Ulugbek, Tashkent, Uzbekistan. Email: shah.abdullayeva@mail.ru.

F.A.Abdullaev, Senior researcher of Uzbekistan Research Institute of Pedagogical Science named after Kary Niazy. Email: f.abdullayev_2015@mail.ru.

(c) The Authors. Published by Blue Eyes Intelligence Engineering and Sciences Publication (BEIESP). This is an open access article under the CC BY-NC-ND license (http://creativecommons.org/licenses/by-nc-nd/4.0/) problem and the research topic is determined by the social order of society to ensure the quality of professional education that meets the needs of the modern labor market and the requirements of international standards.

The scientific and theoretical level of relevance of the study is determined by the existence of various approaches to the methodology of teaching university students and students of the continuing education system using information and communication technologies (ICT). Analysis of the state of the problem showed that the available methods can only monitor or control the level of training of university students and students of the continuing education system in the field of ICT. There was a need to develop teaching methods for university students and students of the continuing education system in the context of using intelligent information systems. It should be noted that scientific and theoretical approaches are not fully used in the training of university students and students of the continuing education system in the disciplines of specialization.

At the scientific and methodological level, the relevance of the study is due to the fact that the educational and cognitive potential of ICT is not fully used in education, the disclosure of which presents certain difficulties. The structure of ICT should highlight the direction of "Information Technology" and "Innovative Learning Technology" with its applied aspect in the form of intelligent information systems, modular training systems, which allows us to talk about the available methodological potential of this area at this stage of the development of the education system. Educational and methodological support has not been developed in a number of disciplines, there are no teaching methods for students in these disciplines, which means that the task is to develop a method using an intelligent information system that contributes to the success of student learning.

\section{LITERATURE REVIEW}

The theoretical and methodological basis of the study is the general didactic provisions, principles and criteria for optimizing the organization of training (Yu.K. Babansky, V.P. Bespalko, A. Abdukadyrov, etc.); scientific foundations of the organization of the educational process at the university (U. Begimkulov, T. 
Shoimardonov, S.I. Zinoviev, etc.); activity approach to understanding personality development (L.S. Vygotsky, D.Ruzieva and others). O.A.'s works are devoted to the problem of professional training of a specialist with higher pedagogical, including vocational and pedagogical education. Abdulina, S.I. Arkhangelsk, A.C. Belkina et al.

The study reflected the provisions of the theory of pedagogical technology (A.C. Belkin, V.P. Bespalko, B. Bloom, etc.); problems of informatization of education (Y. A. Vagramenko, B. S. Gershunsky, and N. Rustamova, etc.). However, despite the sufficient number of works devoted to the methodology of teaching students, the problem under study is not yet fully resolved, in particular, the activating role of ICT is not sufficiently developed.

\section{METHODOLOGY, THEORY AND DISCUSSION}

The main concepts of the study include:

Information and communication technologies - the processes of accumulation, storage, transmission, processing, control of information based on the use of computer technology, communications and the latest information transformation technologies.

An information system is a human-organized system for collecting, storing, processing and issuing information necessary for the effective functioning of subjects and objects of management.

Artificial intelligence is the property of automatic systems to take on individual functions of human intelligence, for example, to choose and make optimal decisions based on previous experience and a rational analysis of external influences.

Intelligent information system is an information system that can draw logical conclusions based on knowledge in a specific subject area and provides a solution to the tasks set by the user, therefore it should be endowed with functions that allow solving problems that cannot be solved correctly in the absence of an expert (specialist in a specific subject area)

A comprehensive analysis of the state of the methodology for teaching students of computer specializations using ICTs, as well as modern research on this topic, allowed us to highlight a number of contradictions:

- between the accelerating process of informatization, under the influence of which all spheres of human life undergo changes, including education, and the use of traditional approaches to organizing and teaching methods for university students and students of the continuing education system;

- the need for informatization of the educational space, analysis and generalization of the productive use of PIKT and insufficient development of their didactic potential for teaching university students and students of the continuing education system;

- awareness of the need to orient the learning process towards finding ways to enhance the educational and cognitive activities of students on the basis of self-knowledge and insufficient implementation of the relevant pedagogical conditions;

- the traditionally established teaching methodology for university students and students of the continuing education system and the modern capabilities of intelligent information systems;
- between the practical relevance of the existing didactic potential that intellectual information systems possess, including for training university students and students of the continuing education system, and its insufficient development in the context of using ICTs.

Based on the analysis of relevance, revealed contradictions, the research problem is formulated, which consists in the scientific substantiation of the teaching methods for university students and students of the advanced training system of computer specializations using intelligent information systems.

The purpose of the study is to theoretically substantiate, develop and, in the course of experimental search work, test the training methodology for university students and students of the advanced training system of computer specializations using intelligent information systems.

The object of study is the process of training university students and students of the continuing education system using ICT.

The subject of the study is the pedagogical conditions for teaching university students and students of the advanced training system of computer specializations using intelligent information systems.

The research hypothesis consists of the following assumptions:

- the methodology of teaching university students and students of the system of advanced training for computer specializations will probably be more effective if the didactic potential of intelligent information systems is realized, based on the adaptation of educational material to the level of preparedness of students;

- educational material, apparently, should, in addition to the unity of the substantive and procedural aspects of the educational process, be also structured in accordance with the requirements for the knowledge system adopted in intelligent information systems;

- the effectiveness of the teaching methodology for university students and students of the continuing education system using intelligent information systems, most likely, depends on the validity of the set of pedagogical conditions: timely diagnosis of students' understanding of educational material and the necessary adjustments, development of positive cognitive motivation of students, personification of the educational process, creating a situation of success;

- diagnosis of understanding by students and students of educational material by means of intelligent information systems is likely to be more productive when substantiating and demonstrating in the educational process the mechanisms of formal reasoning carried out using intelligent information systems. The goal, object and subject, as well as the hypothesis put forward, required the solution of the following research tasks:

1. To analyze the theoretical and methodological foundations of the use of ICT in training.

2. To design and implement in the training of university students and students of the advanced training system of computer specializations an intelligent information system that demonstrates the didactic potential of these systems. 
3. To substantiate the criteria for the levels of understanding by university students and students of the advanced training system of educational material and formalize them, laying in the capabilities of an intelligent information system.

4. To develop methods and means of teaching university students and students of the advanced training system of computer specializations using intelligent information systems.

5. Experimental search to verify the effectiveness of the developed methodology.

\section{EXPERIMENTAL RESULTS}

To solve the tasks, the following research methods were used: theoretical - study and analysis of philosophical, psychological, pedagogical and scientific-methodical literature, as well as educational documents, existing curricula of specialties and programs of disciplines "Information Technologies", "Innovative Learning Technologies" identification of the conceptual field of the problem, synthesis, comparison, generalization, classification, modeling; empirical-pedagogical observation, testing, ranking, analysis of student work, diagnosis of understanding levels, statistical processing of research results, their pedagogical interpretation, conducting experimental-search work.

Research base. The study was carried out at the National University of Uzbekistan with students of the Faculty of Informatics, with students of the Tashkent State Pedagogical University, as well as with students of the continuing education system for teachers at Tashkent State Pedagogical University. The experiment involved 263 students and students.

The main stages of the study were carried out in three stages:

At the first stage, search and theoretical, a theoretical study was conducted of the problem of finding methods for teaching students of computer specializations using ICTs based on the analysis of philosophical, psychological, pedagogical and methodological literature, which made it possible to formulate the initial positions of the study, to determine the object, subject and its conceptual categorical apparatus. The didactic potential of intelligent information systems was revealed, a methodology for teaching university students and students of the advanced training system for computer specializations using intelligent information systems was developed, and a ascertaining stage of experimental search was carried out.

At the second stage, an experimental search, a methodology for teaching students of computer specializations using an intelligent information system was implemented and the didactic potential of intelligent information systems was revealed. The formative stage of the experimental research work was carried out, during which the students' knowledge was diagnosed.

At the third stage, generalizing, analysis, generalization, systematization and final processing of the results of the experimental-search work were carried out, conclusions and recommendations were clarified, the text of the dissertation was drawn up.

The reliability and validity of the results obtained in the dissertation on the actualized problem are determined by the initial methodological positions; using a set of complementary methods of pedagogical research that are adequate to the goals and objectives; systematic tracking of results at different stages of experimental search work; using probabilistic and statistical methods for processing research data.

Table I: Statistical analysis sample rates

\begin{tabular}{|c|c|c|c|c|c|c|c|}
\hline \multirow{3}{*}{ 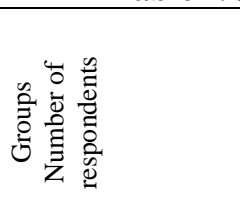 } & \multirow{3}{*}{ 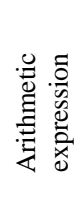 } & \multicolumn{6}{|c|}{ Level indicators } \\
\hline & & \multicolumn{3}{|c|}{$\begin{array}{c}\text { At the } \\
\text { beginning }\end{array}$} & \multicolumn{3}{|c|}{ In the end } \\
\hline & & .0.0 & $\stackrel{\square}{\Sigma}$ & ב్త & . ㅁำ & $\stackrel{\square}{\Sigma}$ & 3. \\
\hline $\begin{array}{l}\text { Experimental group } \\
n_{\mathrm{i}}=132\end{array}$ & $\mathrm{X}_{\mathrm{i}}$ & 29 & 41 & 62 & 37 & 55 & 40 \\
\hline $\begin{array}{l}\text { Control group } \\
n_{\mathrm{i}}=131\end{array}$ & $\mathrm{Y}_{\mathrm{j}}$ & 27 & 40 & 64 & 29 & 44 & 58 \\
\hline
\end{tabular}

Figure 1. Level of respondents' knowledge (beginning of the experiment)

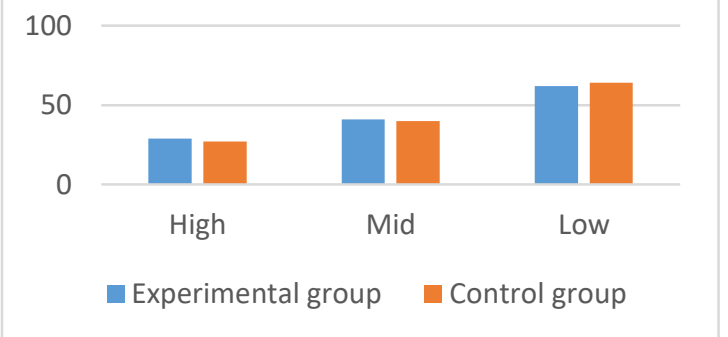

Figure 1. Level of respondents' knowledge (end of the experiment)

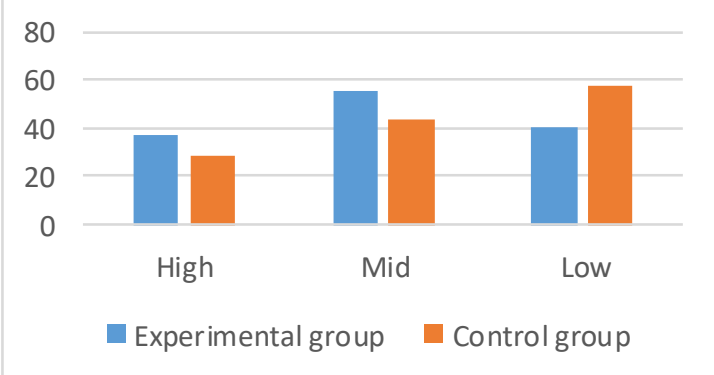

The research results do not pretend to be an exhaustive solution to the problem of training students in computer specializations using intelligent information systems. A promising area for further scientific research, in our opinion, is a more detailed study of the issues of the effective use of intelligent information systems in the process of training future and current specialists.

\section{CONCLUSION}

In the process of the study, the initial hypothesis was fully confirmed, the tasks set were solved, and the following results and conclusions were obtained. 
1. The state of the problem under study in philosophical, psychological, pedagogical and scientific-methodical literature was analyzed, which allowed us to focus on scientific and methodological approaches to teaching university students and students of the advanced training system of computer specializations using ICT.

2. The necessary and sufficient pedagogical conditions for training university students and students of the system of advanced training of computer specializations using intelligent information systems are identified, namely:

- timely diagnosis of students' understanding of educational material and the necessary adjustments;

- development of positive cognitive motivation of students, aimed at achieving an understanding of educational material;

- personification of the educational process based on the use of intelligent information systems in training;

- Creation in the classroom of a success situation conducive to the transformation of students from learning objects into subjects of cognitive activity based on understanding.

3. It has been established that the didactic potential of intelligent information systems under certain pedagogical conditions becomes a real factor in enhancing understanding of theoretical material in training, enhancing the educational and cognitive activity of the student, focused on the development of the personality of the student.

4. The didactic potential of intelligent information systems for teaching students based on:

- high information content, contributing to the development of the personality of the student;

- emotional richness of the content of training, actively influencing the perception of information;

- saturation with cognitive facts, fostering the logic of thinking;

- creating the conditions for independent study of material (self-education) using an intellectual information system that allows a student to comprehend difficult at the level of understanding, choose a convenient time and place for academic work, as well as the rate of learning;

- ensuring differentiation and personification of training;

- adaptation of educational material for a more objective assessment of students' knowledge and skills.

5. A methodology has been developed for teaching students of computer specializations using intelligent information systems, which describes the implementation of pedagogical conditions for using the didactic potential of intelligent information systems. The selected conditions determined the carrying out of experimental-search work on training students in computer specializations, focused on the assimilation by them of educational material by means of intelligent information systems when we fulfill the necessary and sufficient pedagogical conditions justified by us.

6. The experimental research work confirmed the effectiveness of the developed methodology, which was confirmed by statistical processing of the results, as well as interpretation of the results of statistical analysis.

\section{REFERENCES}

1. Abduqodirov A.A. Teoriya i praktika intensifikatsii podgotovki uchiteley fiziko-matematicheskix dissiplin: Aspekt ispolzovaniya kompyuternix sredstv $\mathrm{v}$ uchebno-vospitatelnom protsesse dissertatsiya ... doktora pedagogicheskix nauk : 13.00.01, Tashkent gos. ped. in-t im. Nizami, Tashkent, 1990, pp. 312-334.

2. Andreev A. B., Moiseev V. B., Usmanov V. V., Usachev Ju. E. Ispol'zovanie jekspertnyh sistem dlja analiza znanij uchashhihsja $\mathrm{v}$ srede otkrytogo obrazovanija. // Telekommunikacii i informatizacija obrazovanija. 2002. No. 3. pp. 35-53.

3. Arhangel'skij S.I. Kiberneticheskie analogii v obuchenii. Moscow: Znanie, 1968.p. 42.

4. Arkhangelsk, Arhangel'skij S.I. Uchebnyj process v vysshej shkole, ego zakonomernye osnovy i metody. Moscow: 1989. - pp.301-368.

5. Babanskij Ju.K. Problemy povyshenija jeffektivnosti pedagogicheskih issledovanij: (Didakticheskij aspekt). - Moscow: Pedagogika, 1982. pp. 145-192.

6. Begimkulov U.Sh. Pedagogik talim zharajonlarini ahborotlashtirishni tashkil etish va boshkarish nazarijasi va amalijoti: Ped.fanl.dokt. ... diss. - Tashkent: 2007. - p. 305.

7. Belkin A.C. Vozrastnaja pedagogika. Ekaterinburg, 1999. p.269.

8. Bespal'ko V.P. Programmirovannoe obuchenie. Didakticheskie osnovy. Moscow: Vysshaja shkola, 1970. p.300.

9. Bloom B.S. (ed) et al. A taxonomy of Educational objectives: Handbook 1: The Cognitive Domain. Harvow, 1956.

10. Chelysheva I.V. Metodika i tehnologi mediaobrazovanija v shkole i vuze. Centr razvitija lichnosti. Taganrog. 2009.

11. Fateeva I.A. Mediaobrazovanie: teoreticheskie osnovy i opyt realizacii / Monografija. - Cheljabinsk: Izd-vo Cheljab. GU, 2007. - p. 270.

12. Fedorov A.V. Mediaobrazovanie v nemeckojazychnyh stranah // Distancionnoe i virtual'noe obuchenie. - Moscow: 2010. No. 4. - p. 300 .

13. Fedorov A.V., Mediaobrazovanie i mediagramotnost' / Ucheb. posobie dlja vuzov. - Moscow: Vlados, 2007. - p. 178.

14. Gluhanjuk N. S. Psihologicheskie osobennosti i zakonomernosti professional'no-pedagogicheskoj dejatel'nosti // Obrazovanie i nauka: Izv. Ural, nauch.-obrazovat. centra RAO. 2000. - No. 3 (5). - pp. 152 162.

15. Hart A. Teaching the Media. International Perspectives. - London: Lawrence Erlbaum Assoc, Publishers, 1998. - pp. 1-21.

16. Rustamova N.R. Media culture as a developing factor of rational thinking of secondary school students//European Journal of Science and Research Reflection in Educational Sciences (EJRRES), Special Issue - Great Britain, 2019, Volume No.3, Speccial Issue, pp. 58-64.

17. Rustamova N.R. The Technology of Developing Media Culture in Secondary School Students. International Journal of Innovative Technology and Exploring Engineering (IJITEE), ISSN: 2278-3075 Volume-IX, Issue-II, December 2019.

18. Ruzieva D. Ruzieva D. The influence of preparation of pedagogical staff on the progressive development of Uzbekistan. Research Result Network Scientific Journal. Moscow: 2018. Aviable to: http://research-result.ru/journal/download/1327.

19. Shojimardonov T. "Elektron pedagogika va pedagogning shahsij, kasbij ahborot majdonini lojihalash" moduli bujicha UUM. Tashkent: UzMU huzuridagi pedagog kadrlarni kajta tajjorlash va ularning malakasini oshirish Mintaqavij markazi, 2015. - p. 136.

20. Vagramenko Ja.A. Informacionnye tehnologii i modernizacija obrazovanija. // Pedagogicheskaja informatika, 2000, No.2. Moscow. pp. $5-6$.

21. Vygotsky L.S. Sobranie sochinenii. 1st book. Moscow: Pedagogika publishing house. 1982.

22. Zaikina L.Ju. Sistema upravlenija kachestva obuchenija informatike studentov vuzov: Avtoref. dis.kand. ped. nauk. Moscow., 2006.

\section{AUTHORS PROFILE}

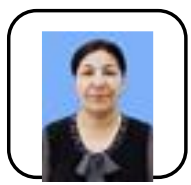

Ruzieva Dilnoz Isamjanovna obtained her Bachelors and Master's Degree in Russian Language from The Tashkent State Pedagogical Institute. She received her D.Sc. degree from Tashkent State Pedagogical University named after Nizami, Tashkent city, Uzbekistan, 2007. She has published more than 60 Journals and 75 papers in both national and international conferences. 
Abdullaeva Shahzoda Abdullaevna obtained her Bachelors and Master's Degree in Russian Language \& Literature from The Tashkent State Pedagogical Institute. She received her D.Sc. degree from Tashkent State Pedagogical University named after Nizami, Tashkent city, Uzbekistan, 2005. She has published more than 100 Journals and 200 papers in both national and international conferences.

Abdullaev Farhod Abdurashidovich obtained his Bachelors and Master's Degree in Radio techniques from The Tashkent University of IT. He has published more than 20 Journals and 30 papers in both national and international conferences. 